\title{
Editorial: Veterinary Reproductive Immunology
}

\author{
Dariusz J. Skarzynski ${ }^{1}$, Fuller W. Bazer ${ }^{2}$ and Juan G. Maldonado-Estrada ${ }^{3 *}$ \\ ${ }^{1}$ Department of Reproductive Immunology and Pathology, Institute of Animal Reproduction and Food Research, Polish \\ Academy of Science, Olsztyn, Poland, ${ }^{2}$ Department of Animal Science, Texas A\&M University, College Station, TX, \\ United States, ${ }^{3} \mathrm{OHVRI}$ Research Group, Escuela de Medicina Veterinaria, Universidad de Antioquia, Medellín, Colombia
}

Keywords: domestic animals, endometrium, fetal allograft, innate immune cells, Medawar paradox, pregnancy loss, reproductive immunology, T-regulatory cells

Editorial on the Research Topic

Veterinary Reproductive Immunology

\section{FROM MEDAWAR'S PARADOX TO NEUROIMMUNOENDOCRINE, METABOLIC AND ENVIRONMENTAL INTEGRATION}

\section{OPEN ACCESS}

Edited and reviewed by:

Ahmed Tibary,

Washington State University,

United States

*Correspondence:

Juan G. Maldonado-Estrada

juan.maldonado@udea.edu.co

Specialty section:

This article was submitted to

Animal Reproduction -

Theriogenology,

a section of the journal

Frontiers in Veterinary Science

Received: 26 November 2021 Accepted: 06 December 2021

Published: 10 January 2022

Citation:

Skarzynski DJ, Bazer FW and

Maldonado-Estrada JG (2022)

Editorial: Veterinary Reproductive

Immunology.

Front. Vet. Sci. 8:823169.

doi: 10.3389/fvets.2021.823169
The field of Reproductive Immunology has evolved from the paradigms of transplantation immunology to an integrated concept of interactions between the endocrine, immune, nervous, and reproductive systems as critical components of the physiology of reproduction. The origin of reproductive immunology was the Medawar paradox when he proposed several theories explaining failure of the mother to reject the fetal allograft in an epoch when the rules of Major Histocompatibility Complex and its compromise in transplantation immunology were defined. From an orthodox immunologist's perspective, it is hard to fully understand the mechanisms underlying maternal-fetal tolerance in mammalian reproduction. Medawar's theories were tested experimentally by several scientists, whose results are considered fundamental to the origin of reproductive immunology. Although Medawar' paradox is considered the inflection point for the origin of reproductive immunology $(1,2)$, Billington (3) stated that Mechnikov and Landsteiner were the pioneers of reproductive immunology with their discoveries of expression of phagocytic cells and $\mathrm{Fc}$ receptors in placentae that are responsible for uptake of placental antibodies in women during gestation. Also, there was the discovery of hemolytic anemia in the rhesus monkey and its treatment with counteracting antibodies, respectively (3). Since the first hypotheses proposed by Medawar on the possible mechanisms of non-rejection of the fetal allografts, to the pioneering studies in rodents and in women undertaken by Beer, Billingham, Scott, and Yang on maternal-fetal tolerance in the 60's (3), pioneers in reproductive immunology have paved the way for current research in reproductive immunology of human and other mammals.

Regarding the compromise of MHC antigens in reproduction, Billington reported that fetal size was greater when female mice produced fetuses from a strain different from their own (4). In this paper, Billington cited early work highlighting the importance of fetal antigens and cells in establishing maternal-fetal tolerance in mice, rats, cattle, and humans. In that epoch, the first report on circulating syncytiotrophoblast fragments in human pregnancy and their possible relationship to maternal tolerance to the fetal allograft (5) provided further evidence of for a relationship to pathologies such as preeclampsia (6).

Several pieces of evidence support the role of fetal MHC antigens in successful pregnancies, depending on the species and stage of gestation (7-12). The presence of maternal cells in the fetal circulation and fetal cells and cell-free DNA trafficking into the maternal circulation was reported for humans [(13-15), and reviewed in (16)], mice (17-19), and domestic animal species (20-22). The trafficking of cells between the mother and the fetus is a crucial component of the interaction 
between maternal and fetal immune cells (13, 23-25), highlighting the importance of maternal cells in "educating" the fetal immune system for the antigenic environment it will face in postnatal life $[(26)$, reviewed in $(27,28)]$. The presence of maternal immune cells at the maternal-fetal interface is accepted as a critical component of the physiology of gestation (29) and in pathological conditions such as hypertensive disorders of pregnancy, including preeclampsia (30-32).

Several authors proposed that fetal cells bearing MHC antigens and other circulating fetal antigens could act as conventional triggers of the maternal cellular immune responses resulting in rejection of the fetal allograft and maternally induced runt disease in the offspring $(33,34)$. Accordingly, the work of led by Clark and Chaouat with the CBA2/DBA model in the 1980s (35-37) provided evidence of immune-mediated fetal resorption. This model helped test several hypotheses on the compromise of stressful conditions in the physiopathology of immune-mediated pregnancy loss.

In the late 1970s and early 1980s, research by Martal et al. $(38,39)$ and Bazer and Roberts group on ovine and bovine trophoblast interferons established the molecular basis of maternal recognition of pregnancy in ruminants (40-42) and triggered an exciting field of research in the maternal-fetal dialogue between the endometrium, the corpus luteum, and the hypothalamic-hypophyseal axis.

The work led by Anne Croy showed the essential role that the trophoblast layer of the placenta plays in maintaining interspecies pregnancies (43). Furthermore, Croy's team (44) and Moffett's group $(45,46)$ provided evidence for the importance of uterine Natural Killer cells, dendritic cells (47), and innate uterine lymphoid cells [reviewed in (48)] for successful pregnancies in mice and humans, highlighting the importance of innate immune cells in the physiology of gestation. Besides, the works by Antczak and Allen on the compromise of the maternal immune response in the developing chorionic girdles in equine placentation in the early 80 's $(49,50)$ provided evidence for the importance of cells of the adaptive immune system in successful placental development and fetal growth in mares.

The proposal of an immunotropic hypothesis (51) elicited new and exciting concepts to the field of reproductive immunology $[(52,53)$, reviewed in $(54,55)]$ and elicited controversy $(56-58)$ on the importance of the adaptive immune system in gestation maintenance. The initial concept of a Th1/Th2 balance required for successful gestation further evolved toward the concept of a balance between regulatory T cells (T-reg) (59) and T-reg/Th17 cells being critical for successful pregnancies $(60,61)$.

From the beginning of the twenty-first century, several studies by Skarzynski's group provided evidence for a neuroimmuno-endocrine interaction between the endometrium and corpus luteum in cattle $(62-67)$ and horses $(68,69)$ and the role epithelial cells play in the maternal-fetal dialogue (70). Concomitantly, there were results from Bazer's group on the compromise of several modulators in the maternalfetal dialogue in sheep (71-75) add critical evidence regarding the function of the reproductive system as an integrated system in which neuro-immune-endocrine and metabolic cues are integrated for successful reproduction (or failure if loss of homeostasis). Other research groups around the world provided additional evidence for the importance of cellular and humoral immune components and processes in the physiology of pregnancy $(54,76-79)$. Failure in several processes were implicated in immune-mediated embryonic and fetal losses during the course of gestation [reviewed in $(80)$ ].

In this special edition on Veterinary Reproductive Immunology, several papers contributed to increasing our understanding of neuro-immune-endocrine interactions related to physiological and pathological conditions of gestation. The papers provide novel results related to anti-GnRH vaccines in cats, the establishment of pregnancy in dogs, processes related to endometrial function in cattle, horses, and pigs, and pre-implantation signaling in mice. Further, the papers included address state-of-the-art protocols in molecular biology, providing readers, scientists, and clinicians with advanced concepts on reproductive immunology. The discussion is still open, as mentioned by Billington (3), who proposed that reproductive immunology would continuously provide scientific information and controversy (3), as it is an essential aspect of research and discovery in the field of animal reproduction. New research areas, including glycan expression at the maternal-fetal interface in the placenta of several animal species and humans, are becoming more prominent in reproductive immunology. However, there are still a lack of comprehensive theories integrating the contributions of findings from studies in glycobiology into concepts related to successful mammalian reproduction. Even though there is abundant scientific evidence for the essential roles that signals from immune, endocrine, nervous, epithelial, stromal, and trophoblast cells produce to intercommunicate the endocrine, immune, neural, and reproductive tissues, no explicit theories exist to fully explain the way these systems function and contribute to maintaining the physiology of gestation or why, when the system is altered, there are losses of gestations. For these reasons, in the future, we will seek momentum in research whereby the scientific community will provide an integrated view on the homeostasis required for successful reproduction, including integration of immunology, genomics, proteomics, glycomics, and environmental influences in mammalian reproduction.

\section{AUTHOR CONTRIBUTIONS}

DS discussed and corrected the final version of the manuscript. All authors contributed to the article and approved the submitted version.

\section{FUNDING}

This work was supported by Etrategia de Sostebibilidad de Grupos, CODI, Universidad de Antioquia to JM-E and internal grant of IARFR PAS No 5/FBW/2021 supports to DS. FB was also supported by Grant Arginine and secreted phosphoprotein 1 mediate cell signaling to enhance conceptus development and survival from the National Institute of Food and Agriculture 
(NIFA) as Competitive Grant no. 2016-67015-24958 from the USDA National Institute of Food and Agriculture and Roles of fructose and glucose in growth and development of ovine and porcine conceptuses, Competitive Grant No. 2018-67015-28093.

\section{REFERENCES}

1. Medawar PB. Some immunological and endocrinological problems were raised by the evolution of viviparity in vertebrates. Symp Soc Exp Biol. (1953) 7:320-38.

2. Rendell V, Bath NM, Brennan TV. Medawar's paradox and immune mechanisms of fetomaternal tolerance. OBM Transplant. (2020) 4:26. doi: 10.21926/obm.transplant.2001104

3. Billington WD. Origins and evolution of reproductive immunology: a personal perspective. J Reprod Immunol. (2015) 108:25. doi: 10.1016/j.jri.2014.10.003

4. Billington WD. Influence of immunological dissimilarity of mother and foetus on size of placenta in mice. Nature. (1964) 202:317-8. doi: 10.1038/202317a0

5. Billingham RE. Transplantation immunity and the maternal-fetal relation. $N$ Engl J Med. (1964) 270:720-5. doi: 10.1056/NEJM196404022701406

6. Redman CW, Sargent IL. Microparticles and immunomodulation in pregnancy and preeclampsia. J Reprod Immunol. (2007) 76:61-7. doi: 10.1016/j.jri.2007.03.008

7. Wells M, Hsi BL, Faulk WP. Class I antigens of the major histocompatibility complex on cytotrophoblast of the human placental basal plate. Am J Reprod Immunol. (1984) 6:167-74. doi: 10.1111/j.1600-0897.1984.tb00132.x

8. Billington WD, Burrows FJ. The rat placenta expresses paternal class I major histocompatibility antigens. J Reprod Immunol. (1986) 9:15560. doi: 10.1016/0165-0378(86)90008-2

9. Crump A, Donaldson WL, Miller J, Kydd JH, Allen WR, Antczak DF. Expression of major histocompatibility complex (MHC) antigens on horse trophoblast. J Reprod Fertil Suppl. (1987) 35:379-88.

10. Hunt JS, Fishback JL, Andrews GK, Wood GW. Expression of class I HLA genes by trophoblast cells. Analysis by in situ hybridization. J Immunol. (1988) 140:1293-99.

11. Redline RW, Lu CY. Localization of fetal major histocompatibility complex antigens and maternal leukocytes in murine placenta. Implications for maternal-fetal immunological relationship. Lab Invest. (1989) 61:27-36.

12. Donaldson WL, Zhang $\mathrm{CH}$, Oriol JG, Antczak DF. Invasive equine trophoblast expresses conventional class I major histocompatibility complex antigens. Development. (1990) 110:63-71

13. Herzenberg LA, Bianchi DW, Schröder J, Cann HM, Iverson GM. Fetal cells in the blood of pregnant women: detection and enrichment by fluorescence-activated cell sorting. Proc Natl Acad Sci USA. (1979) 76:14535. doi: 10.1073/pnas.76.3.1453

14. Lo YM, Lo ES, Watson N, Noakes L, Sargent IL, Thilaganathan B, et al. Twoway cell traffic between mother and fetus: biologic and clinical implications. Blood. (1996) 88:4390-5.

15. Adams Waldorf KM, Gammill HS, Lucas J, Aydelotte TM, Leisenring WM, Lambert NC, et al. Dynamic changes in fetal microchimerism in maternal peripheral blood mononuclear cells, CD4+ and CD8+ cells in normal pregnancy. Placenta. (2010) 31:589-94. doi: 10.1016/j.placenta.2010.04.013

16. Bianchi DW, Khosrotehrani K, Way SS, MacKenzie TC, Bajema I, O'Donoghue K. Forever connected: the lifelong biological consequences of fetomaternal and maternofetal microchimerism. Clin Chem. (2021) 67:35162. doi: 10.1093/clinchem/hvaa304

17. Khosrotehrani K, Wataganara T, Bianchi DW, Johnson KL. Fetal cellfree DNA circulates in the plasma of pregnant mice: relevance for animal models of fetomaternal trafficking. Hum Reprod. (2004) 19:24604. doi: 10.1093/humrep/deh445

18. Vernochet C, Caucheteux SM, Kanellopoulos-Langevin C. Bi-directional cell trafficking between mother and fetus in mouse placenta. Placenta. (2007) 28:639-49. doi: 10.1016/j.placenta.2006.10.006

19. Zeng XX, Tan KH, Yeo A, Sasajala P, Tan X, Xiao ZC, et al. Pregnancy-associated progenitor cells differentiate and mature

\section{ACKNOWLEDGMENTS}

The authors thank to their corresponding institutions for financial support of their research and academic activities. into neurons in the maternal brain. Stem Cells Dev. (2010) 19:1819-30. doi: 10.1089/scd.2010.0046

20. McConico A, Butters K, Lien K, Knudsen B, Wu X, Platt JL, et al. In utero cell transfer between porcine littermates. Reprod Fertil Dev. (2011) 23:297302. doi: 10.1071/RD10165

21. Gash KK, Yang M, Fan Z, Regouski M, Rutigliano HM, Polejaeva IA. Assessment of microchimerism following somatic cell nuclear transfer and natural pregnancies in goats. J Anim Sci. (2019) 97:3786-94. doi: 10.1093/jas/skz248

22. Brown JA, Niland ES, Pierce NL, Taylor JB. Validation of fetal microchimerism after pregnancy in the ovine using qPCR. Transl Anim Sci. (2021) 5:txab100. doi: 10.1093/tas/txab100

23. Piotrowski P, Croy BA. Maternal cells are widely distributed in murine fetuses in utero. Biol Reprod. (1996) 54:1103-10. doi: 10.1095/biolreprod54.5.1103

24. Bonney EA, Matzinger P. The maternal immune system's interaction with circulating fetal cells. J Immunol. (1997) 158:40-7.

25. Marleau AM, Greenwood JD, Wei Q, Singh B, Croy BA. Chimerism of murine fetal bone marrow by maternal cells occurs in late gestation and persists into adulthood. Lab Invest. (2003) 83:673-81. doi: 10.1097/01.lab.0000067500.85003.32

26. Khosrotehrani K, Johnson KL, Guégan S, Stroh H, Bianchi DW. Natural history of fetal cell microchimerism during and following murine pregnancy. J Reprod Immunol. (2005) 66:1-12. doi: 10.1016/j.jri.2005.02.001

27. Stelzer IA, Thiele K, Solano ME. Maternal microchimerism: lessons learned from murine models. J Reprod Immunol. (2015) 108:12-25. doi: 10.1016/j.jri.2014.12.007

28. Stelzer IA, Urbschat C, Schepanski S, Thiele K, Triviai I, Wieczorek $A$, et al. Vertically transferred maternal immune cells promote neonatal immunity against early life infections. Nat Commun. (2021) 12:4706. doi: 10.1038/s41467-021-24719-z

29. Craven CM, Ward K. Syncytiotrophoblastic fragments in firsttrimester decidual veins: evidence of placental perfusion by the maternal circulation early in pregnancy. Am J Obstet Gynecol. (1999) 181:455-9. doi: 10.1016/s0002-9378(99)70578-8

30. Huppertz B, Kingdom J, Caniggia I, Desoye G, Black S, Korr H, et al. Hypoxia favours necrotic versus apoptotic shedding of placental syncytiotrophoblast into the maternal circulation. Placenta. (2003) 24:18190. doi: $10.1053 /$ plac. 2002.0903

31. Wei J, Blenkiron C, Tsai P, James JL, Chen Q, Stone PR, et al. Placental trophoblast debris mediated feto-maternal signalling via small RNA delivery: implications for preeclampsia. Sci Rep. (2017) 7:14681. doi: 10.1038/s41598-017-14180-8

32. Carrasco-Wong I, Aguilera-Olguín M, Escalona-Rivano R, Chiarello DI, Barragán-Zúñiga LJ, Sosa-Macías M, et al. Syncytiotrophoblast stress in early onset preeclampsia: the issues perpetuating the syndrome. Placenta. (2021) 113:57-66. doi: 10.1016/j.placenta.2021.05.002

33. Beer AE, Billingham RE, Yang SL. Maternally induced transplantation immunity, tolerance, and runt disease in rats. J Exp Med. (1972) 135:80826. doi: $10.1084 /$ jem.135.4.808

34. Beer AE, Billingham RE. Maternally acquired runt disease. Science. (1973) 179:240-3. doi: 10.1126/science.179.40 70.240

35. Clark DA, Croy BA, Rossant J, Chaouat G. Immune presensitization and local intrauterine defences as determinants of success or failure of murine interspecies pregnancies. J Reprod Fertil. (1986) 77:63343. doi: 10.1530/jrf.0.0770633

36. Clark DA, Chaouat G, Guenet JL, Kiger N. Local active suppression and successful vaccination against spontaneous abortion in CBA/J mice. $J$ Reprod Immunol. (1987) 10:79-85. doi: 10.1016/0165-0378(87)90 052-0 
37. Chaouat G, Menu E, Clark DA, Dy M, Minkowski M, Wegmann TG. Control of fetal survival in CBA x DBA/2 mice by lymphokine therapy. J Reprod Fertil. (1990) 89:447-58. doi: 10.1530/jrf.0.0890447

38. Martal J, Lacroix MC, Loudes C, Saunier M, Wintenberger-Torrès S. Trophoblastin, an antiluteolytic protein present in early pregnancy in sheep. $J$ Reprod Fertil. (1979) 56:63-73. doi: 10.1530/jrf.0.0560063

39. Charpigny G, Reinaud P, Huet JC, Guillomot M, Charlier M, Pernollet JC, et al. High homology between a trophoblastic protein (trophoblastin) isolated from ovine embryo and alpha-interferons. FEBS Lett. (1988) 228:1216. doi: 10.1016/0014-5793(88)80574-x

40. Godkin JD, Bazer FW, Moffatt J, Sessions F, Roberts RM. Purification and properties of a major, low molecular weight protein released by the trophoblast of sheep blastocysts at day 13-21. J Reprod Fertil. (1982) 65:14150. doi: 10.1530/jrf.0.0650141

41. Godkin JD, Bazer FW, Roberts RM. Ovine trophoblast protein 1, an early secreted blastocyst protein, binds specifically to uterine endometrium and affects protein synthesis. Endocrinology. (1984) 114:120-30. doi: 10.1210/endo-114-1-120

42. Helmer SD, Hansen PJ, Anthony RV, Thatcher WW, Bazer FW, Roberts RM. Identification of bovine trophoblast protein-1, a secretory protein immunologically related to ovine trophoblast protein-1.J Reprod Fertil. (1987) 79:83-91. doi: 10.1530/jrf.0.0790083

43. Croy BA, Rossant J, Clark DA. Histological and immunological studies of post implantation death of Mus caroli embryos in the Mus musculus uterus. J Reprod Immunol. (1982) 4:277-93. doi: 10.1016/0165-0378(82)90003-1

44. Croy BA, Gambel P, Rossant J, Wegmann TG. Characterization of murine decidual natural killer (NK) cells and their relevance to the success of pregnancy. Cell Immunol. (1985) 93:31526. doi: 10.1016/0008-8749(85)90137-6

45. Trundley A, Moffett A. Human uterine leukocytes and pregnancy. Tissue Antigens. (2004) 63:1-12. doi: 10.1111/j.1399-0039.2004.00170.x

46. Moffett A, Loke C. Immunology of placentation in eutherian mammals. Nat Rev Immunol. (2006) 6:584-94. doi: 10.1038/nri1897

47. Gardner L, Moffett A. Dendritic cells in the human decidua. Biol Reprod. (2003) 69:1438-46. doi: 10.1095/biolreprod.103.017574

48. Huhn O, Zhao X, Esposito L, Moffett A, Colucci F, Sharkey AM. How do uterine natural killer and innate lymphoid cells contribute to successful pregnancy? Front Immunol. (2021) 12:607669. doi: 10.3389/fimmu.2021.607669

49. Antczak DF, Allen WR. Invasive trophoblast in the genus Equus. Ann Immunol. (1984) 135D:325-31. doi: 10.1016/s0769-2625(84)81201-5

50. Allen WR, Skidmore JA, Stewart F, Antczak DF. Effects of fetal genotype and uterine environment on placental development in equids. J Reprod Fertil. (1993) 98:55-60. doi: 10.1530/jrf.0.0980055

51. Wegmann TG, Lin H, Guilbert L, Mosmann TR. Bidirectional cytokine interactions in the maternal-fetal relationship: is successful pregnancy a TH2 phenomenon? Immunol Today. (1993) 14:353-6. doi: 10.1016/0167-5699(93)90235-D

52. Oliveira LJ, Mansouri-Attia N, Fahey AG, Browne J, Forde N, Roche JF, et al. Characterization of the Th profile of the bovine endometrium during the oestrous cycle and early pregnancy. PLoS ONE. (2013) 8:e75571. doi: 10.1371/journal.pone.0075571

53. Ealy AD, Speckhart SL, Wooldridge LK. Cytokines that serve as embryokines in cattle. Animals. (2021) 11:2313. doi: 10.3390/ani11082313

54. Piccinni MP, Raghupathy R, Saito S, Szekeres-Bartho J. Cytokines, hormones and cellular regulatory mechanisms favoring successful reproduction. Front Immunol. (2021) 12:717808.

55. Wang P, Jiang G, Ju W, Cai Y, Wang J, Wu F. Influence of Bushen Tiaochong cycle therapy on Th1/Th2 deviation, sex hormone level, and pregnancy outcome of alloimmune recurrent spontaneous abortion. Evid Based Complement Alternat Med. (2021) 2021:8624414. doi: 10.1155/2021/8624414

56. Billington WD. Species diversity in the immunogenetic relationship between mother and fetus: is trophoblast insusceptibility to immunological destruction the only essential common feature for the maintenance of allogeneic pregnancy? Exp Clin Immunogenet. (1993) 10:73-84.

57. Chaouat G. The Th1/Th2 paradigm: still important in pregnancy? Semin Immunopathol. (2007) 29:95-113. doi: 10.1007/s00281-007-0069-0
58. Chaouat G. Inflammation, NK cells and implantation: friend and foe (the good, the bad and the ugly?): replacing placental viviparity in an evolutionary perspective. J Reprod Immunol. (2013) 97:2-13. doi: 10.1016/j.jri.2012.10.009

59. Maeda Y, Ohtsuka H, Tomioka M, Oikawa M. Effect of progesterone on Th1/Th2/Th17 and regulatory $\mathrm{T}$ cell-related genes in peripheral blood mononuclear cells during pregnancy in cows. Vet Res Commun. (2013) 37:43-9. doi: 10.1007/s11259-012-9 545-7

60. Huang N, Chi H, Qiao J. Role of regulatory T cells in regulating fetal-maternal immune tolerance in healthy pregnancies and reproductive diseases. Front Immunol. (2020) 11:1023. doi: 10.3389/fimmu.2020.01023

61. Tsuda S, Nakashima A, Morita K, Shima T, Yoneda S, Kishi H, et al. The role of decidual regulatory $\mathrm{T}$ cells in the induction and maintenance of fetal antigen-specific tolerance: imbalance between regulatory and cytotoxic T cells in pregnancy complications. Hum Immunol. (2021) 82:34652. doi: 10.1016/j.humimm.2021.01.019

62. Miyamoto Y, Skarzynski DJ, Okuda K. Is tumor necrosis factor alpha a trigger for the initiation of endometrial prostaglandin $\mathrm{F}$ (2alpha) release at luteolysis in cattle? Biol Reprod. (2000) 62:1109-15. doi: 10.1095/biolreprod62.5.1109

63. Murakami S, Miyamoto Y, Skarzynski DJ, Okuda K. Effects of tumor necrosis factor-alpha on secretion of prostaglandins E2 and F2alpha in bovine endometrium throughout the estrous cycle. Theriogenology. (2001) 55:166778. doi: 10.1016/s0093-691x(01)00511-8

64. Okuda K, Kasahara Y, Murakami S, Takahashi H, WoclawekPotocka I, Skarzynski DJ. Interferon-tau blocks the stimulatory effect of tumor necrosis factor-alpha on prostaglandin F2alpha synthesis by bovine endometrial stromal cells. Biol Reprod. (2004) 70:191-7. doi: 10.1095/biolreprod.103.019083

65. Nishimura R, Bowolaksono A, Acosta TJ, Murakami S, Piotrowska K, Skarzynski DJ, et al. Possible role of interleukin-1 in the regulation of bovine corpus luteum throughout the luteal phase. Biol Reprod. (2004) 71:168893. doi: 10.1095/biolreprod.104.032151

66. Skarzynski DJ, Piotrowska KK, Bah MM, Korzekwa A, Woclawek-Potocka I, Sawai K, et al. Effects of exogenous tumour necrosis factor-alpha on the secretory function of the bovine reproductive tract depend on tumour necrosis factor-alpha concentrations. Reprod Domest Anim. (2009) 44:3719. doi: 10.1111/j.1439-0531.2007.01016.x

67. Duong HT, Piotrowska-Tomala KK, Acosta TJ, Bah MM, Sinderewicz E, Majewska M, et al. Effects of cortisol on pregnancy rate and corpus luteum function in heifers: an in vivo study. J Reprod Dev. (2012) 58:22330. doi: 10.1262/jrd.11-122t

68. Galvão A, Skarzynski DJ, Szóstek A, Silva E, Tramontano A, Mollo A, et al. Cytokines tumor necrosis factor- $\alpha$ and interferon $-\gamma$ participate in modulation of the equine corpus luteum as autocrine and paracrine factors. J Reprod Immunol. (2012) 93:28-37. doi: 10.1016/j.jri.2011.11.002

69. Rebordão MR, Amaral A, Fernandes C, Silva E, Lukasik K, SzóstekMioduchowska A, et al. Enzymes present in neutrophil extracellular traps may stimulate the fibrogenic PGF2 $\alpha$ pathway in the mare endometrium. Animals. (2021) 11:2615. doi: 10.3390/ani11092615

70. Okuda K, Sakumoto R, Okamoto N, Acosta TJ, Abe H, Okada H, et al. Cellular localization of genes and proteins for tumor necrosis factor- $\alpha$ (TNF), TNF receptor types I and II in bovine endometrium. Mol Cell Endocrinol. (2010) 330:41-8. doi: 10.1016/j.mce.2010.07.025

71. Choi Y, Johnson GA, Spencer TE, Bazer FW. Pregnancy and interferon tau regulate major histocompatibility complex class I and beta2microglobulin expression in the ovine uterus. Biol Reprod. (2003) 68:1703-10. doi: 10.1095/biolreprod.102.012708

72. Wang X, Frank JW, Xu J, Dunlap KA, Satterfield MC, Burghardt RC, et al. Functional role of arginine during the peri-implantation period of pregnancy. II. Consequences of loss of function of nitric oxide synthase NOS3 mRNA in ovine conceptus trophectoderm. Biol Reprod. (2014) 91:59. doi: 10.1095/biolreprod.114.121202

73. Lenis YY, Johnson GA, Wang X, Tang WW, Dunlap KA, Satterfield $\mathrm{MC}$, et al. Functional roles of ornithine decarboxylase and arginine decarboxylase during the peri-implantation period of pregnancy in sheep. J Anim Sci Biotechnol. (2018) 9:10. doi: 10.1186/s40104-017-0 225-x 
74. Halloran KM, Stenhouse C, Wu G, Bazer FW. Arginine, agmatine, and polyamines: key regulators of conceptus development in mammals. Adv Exp Med. Biol. (2021) 1332:1385-105. doi: 10.1007/978-3-030-74180-8_6

75. Hoskins EC, Halloran KM, Stenhouse C, Moses RM, Dunlap KA, Satterfield $\mathrm{MC}$, et al. Pre-implantation exogenous progesterone and pregnancy in sheep: I. polyamines, nutrient transport, and progestamedins. J Anim Sci Biotechnol. (2021) 12:39. doi: 10.1186/s40104-021-00554-6

76. Co EC, Gormley M, Kapidzic M, Rosen DB, Scott MA, Stolp HA, et al. Maternal decidual macrophages inhibit NK cell killing of invasive cytotrophoblasts during human pregnancy. Biol Reprod. (2013) 88:155. doi: 10.1095/biolreprod.112.099465

77. Fu B, Wei H. Decidual natural killer cells and the immune microenvironment at the maternal-fetal interface. Sci China Life Sci. (2016) 59:122431. doi: 10.1007/s11427-016-0337-1

78. Alok A, Karande AA. The role of glycodelin as an immune-modulating agent at the feto-maternal interface. J Reprod Immunol. (2009) 83:1247. doi: 10.1016/j.jri.2009.06.261

79. Jena SR, Nayak J, Kumar S, Kar S, Dixit A, Samanta L. Paternal contributors in recurrent pregnancy loss: cues from comparative proteome profiling of seminal extracellular vesicles. Mol Reprod Dev. (2021) 88:96-112. doi: 10.1002/mrd.2 3445
80. Xu L, Li Y, Sang Y, Li DJ, Du M. Crosstalk between trophoblasts and decidual immune cells: the cornerstone of maternal-fetal immunotolerance. Front Immunol. (2021) 12:642392. doi: 10.3389/fimmu.2021.642392

Conflict of Interest: The authors declare that the research was conducted in the absence of any commercial or financial relationships that could be construed as a potential conflict of interest.

Publisher's Note: All claims expressed in this article are solely those of the authors and do not necessarily represent those of their affiliated organizations, or those of the publisher, the editors and the reviewers. Any product that may be evaluated in this article, or claim that may be made by its manufacturer, is not guaranteed or endorsed by the publisher.

Copyright (c) 2022 Skarzynski, Bazer and Maldonado-Estrada. This is an open-access article distributed under the terms of the Creative Commons Attribution License (CC $B Y)$. The use, distribution or reproduction in other forums is permitted, provided the original author(s) and the copyright owner(s) are credited and that the original publication in this journal is cited, in accordance with accepted academic practice. No use, distribution or reproduction is permitted which does not comply with these terms. 